\title{
About the Optimal Ratio Inhibitor and Activators of Carbon Dioxide Sorption Process by Using Chlorophyll-synthesizing Chlorella microalgae
}

\author{
Vasil Dyachok ${ }^{1 *}$, Solomiia Mandryk ${ }^{1}$, Serhiy Huhlych ${ }^{1}$ \\ 1 Lviv Polytechnic National University, 12 Bandera street, Lviv, 79013, Ukraine \\ * Corresponding author's email: dyachokvasil@gmail.com
}

\begin{abstract}
The suppression of the inhibition effect by $\mathrm{SO}_{2}$ sulfur dioxide with the simultaneous action of two activators $-\mathrm{P}_{2} \mathrm{O}_{5}$ phosphorus oxide and $\mathrm{N}_{\mathrm{x}} \mathrm{O}_{\mathrm{y}}$ nitrogen oxide, as well as the process of carbon dioxide absorption by chlorophyllsynthesizing microalgae Chlorella were studied in this work. The experimental dependences of the $\mathrm{CO}_{2}$ uptake dynamics by microalgae under the conditions of the $\mathrm{SO}_{2}$ inhibitor critical concentration action and the simultaneous presence of $\mathrm{P}_{2} \mathrm{O}_{5}$ and $\mathrm{N}_{x} \mathrm{O}_{y}$ activators were shown. A mathematical description of the Chlorella microalgae biomass growth depending on the $\mathrm{P}_{2} \mathrm{O}_{5}$ and $\mathrm{N}_{x} \mathrm{O}_{y}$ activators concentration, provided that there is a $\mathrm{SO}_{2}$ inhibitor constant concentration was obtained. The optimum values of the $\mathrm{P}_{2} \mathrm{O}_{5}$ phosphorus oxide and $\mathrm{N}_{\mathrm{x}} \mathrm{O}_{\mathrm{y}}$ nitrogen oxides concentration at the $\mathrm{SO}_{2}$ inhibitor critical concentration for the carbon dioxide absorption by chlorophyll-synthesizing microalgae Chlorella process were established.
\end{abstract}

Keywords: Chlorella microalgae, carbon dioxide, phosphorus oxide, nitrogen oxide, sulfur dioxide, inhibitors and activators, mathematical description.

\section{INTRODUCTION}

Global climate change is not just an environmental problem today, but a real threat to the human life. Global warming is caused by the greenhouse gases growth in the atmosphere. This is the result of the rapid industry development and the hydrocarbons combustion, and the environment is neglected and destroyed. The atmospheric carbon concentrations have broken all records in recent years, so addressing the problem of the colossal amount of greenhouse gases is an urgent issue right now (Zmina klimatu...,2020).

The developed countries have already begun to fight for a clean environment and reduction of the anthropogenic burden on the ecosystem a long time ago. Ukraine is also trying to improve the environmental situation, but at the moment the changes are barely noticeable. The European Union has set a goal that by 2050 Europe should become the first continent that does not harm nature. Ukraine is ready to join this goal and become a part of this strategy. In January 2020, the Ministry of Energy and Environmental Protection of Ukraine launched a draft Concept of «green» energy transition of our country until 2050, which is conditioned by the approaches of loyalty to the green energy development in the world and by special attention to climate change. The concept provides for the complete replacement of coal generation and the transition of Ukraine's economy which is based on the use of fossil fuels - coal, oil, gas - to a climateneutral economy in the long term perspective (Uryadovyy portal...,2020).

The government is also beginning to strengthen the environmental control over the air quality. In 2020, the Ministry of Energy plans to build a national monitoring system, which provides for the opening of the «Emission Control Office» and 50 air quality monitoring stations. Thus, these measures will enable to significantly reduce the greenhouse gas emissions into the atmosphere (Ofitsiyhyy portal...,2020). 
The main amount of the greenhouse gas emissions is formed during the combustion of fuel - solid, liquid or gaseous. The main greenhouse gas emitted into the atmosphere is carbon dioxide $\mathrm{CO}_{2}$. Therefore, reducing the $\mathrm{CO}_{2}$ emissions is the main task of today's environmental community.

During the fuel combustion process, concomitant greenhouse gases such as sulfur dioxide $\left(\mathrm{SO}_{2}\right)$, nitrogen oxides $\left(\mathrm{N}_{\mathrm{x}} \mathrm{O}_{\mathrm{y}}\right)$, phosphorus oxide $\left(\mathrm{P}_{2} \mathrm{O}_{5}\right)$ and others are formed. In the context of the carbon dioxide uptake by chlorophyll-synthesizing microalgae under real conditions, it is difficult to expect individual action of the above-mentioned components on the carbon dioxide uptake process. Therefore, it is important to study the simultaneous effect of sulfur dioxide $\left(\mathrm{SO}_{2}\right)$, phosphorus oxide $\left(\mathrm{P}_{2} \mathrm{O}_{5}\right)$, and nitrogen oxides $\left(\mathrm{N}_{\mathrm{x}} \mathrm{O}_{\mathrm{y}}\right)$ on the dynamics of carbon dioxide absorption by chlorophyllsynthesizing microalgae.

Owing to the biological $\mathrm{CO}_{2}$ fixation with the help of chlorophyll-synthesizing microalgae Chlorella, it is possible not only to reduce carbon dioxide emissions, but also to obtain microalgae biomass with a high content of lipids (a source of regenerative energy). Thus, the $\mathrm{CO}_{2}$ fixation based on photosynthesis is the most promising method of purifying the industrial gaseous emissions from carbon dioxide and associated greenhouse gases.

In our previous articles (Dyachok et al., 2017; Dyachok et al., 2020) the sulfur dioxide $\left(\mathrm{SO}_{2}\right)$ inhibitor inactivation phenomenon was studied, separately by phosphorus oxide $\left(\mathrm{P}_{2} \mathrm{O}_{5}\right)$ and nitrogen oxides $\left(\mathrm{N}_{\mathrm{x}} \mathrm{O}_{\mathrm{y}}\right)$ of the carbon dioxide $\left(\mathrm{CO}_{2}\right)$ absorption process. The literature does not contain the information on the simultaneous effect of $\mathrm{SO}_{2}$, $\mathrm{P}_{2} \mathrm{O}_{5}$ and $\mathrm{N}_{x} \mathrm{O}_{\mathrm{y}}$ on the $\mathrm{CO}_{2}$ absorption dynamics. Therefore, it is important to study the simultaneous total effect of $\mathrm{P}_{2} \mathrm{O}_{5}$ and $\mathrm{N}_{\mathrm{x}} \mathrm{O}_{\mathrm{y}}$ at the critical concentration of $\mathrm{SO}_{2}$ inhibitor on the dynamics of the $\mathrm{CO}_{2}$ carbon dioxide uptake by chlorophyllsynthesizing Chlorella microalgae.

The purpose of the work was to establish the optimum ratio of $\mathrm{SO}_{2}$ inhibitor and both $\mathrm{P}_{2} \mathrm{O}_{5}$ and $\mathrm{N}_{\mathrm{x}} \mathrm{O}_{\mathrm{y}}$ activators concentrations at which the carbon dioxide absorption by chlorophyllsynthesizing Chlorella microalgae becomes the most effective.

\section{MATERIAL AND METHODS}

Microalgae mineral nutrition is a set of absorption and assimilation processes of chemical elements necessary for the vital activity of their cells in the form of inorganic salts ions. The most important component of mineral nutrition is inorganic carbon, which enters the nutrient solution due to the bubbling of the environment with air containing $\mathrm{CO}_{2}$, as well as salts of carbonic acid. The nutrient media basis for the microalgae cultivation are aqueous solutions of inorganic salts, which contain nitrogen, calcium, phosphorus and other macro and micronutrients.

Mineral nutrients are absorbed by the entire microalgae cell surface: nitrogen comes in the form of $\mathrm{NO}_{3}^{-}$anion, phosphorus and sulfur - in the form of $\mathrm{H}_{2} \mathrm{PO}_{4}^{-}$and $\mathrm{HSO}_{3}^{-}$anions, while metals in the form of $\mathrm{K}^{+}, \mathrm{Ca}^{2+}, \mathrm{Mg}^{2+}$ cations. The analysis of the microalgae dry mass shows that the carbon content is about $45 \%$, oxygen $-42 \%$, hydrogen $-6-6.5 \%$, nitrogen $-1.5 \%$, ash elements - 5\% (Zolotaryova et al., 2008).

Under artificial conditions, microalgae are grown in the aqueous solutions that contain all the necessary components for growth and development. Such aqueous solutions are called nutrient media. Usually, the choice of the correct nutrient medium determines the quality of further research and the reliability of the results.

There are several types of nutrient media for the microalgae cultivation, which are classified according to various characteristics. One of them is the so-called minimum environment: it contains the minimum content of necessary components for the growth and development of microalgae and includes inorganic salts and water (Khlorella..., 2020). However, it should be noted that there is a natural nutrient medium in which microalgae live and develop under natural conditions (ponds, lakes, seas, etc.).

The same elements as carbon (C), sulfur (S), nitrogen $(\mathrm{N})$ and phosphorus $(\mathrm{P})$ must be present for all types of nutrient media, for microalgae optimum growth and development. When burning fuel, solid, liquid or gaseous, a large amount of $\mathrm{CO}_{2}$ carbon dioxide is formed, which is the main greenhouse gas. Concomitant greenhouse gases, such as phosphorus oxide $\left(\mathrm{P}_{2} \mathrm{O}_{5}\right)$, nitrogen oxides $\left(\mathrm{N}_{\mathrm{x}} \mathrm{O}_{\mathrm{y}}\right)$, sulfur dioxide $\left(\mathrm{SO}_{2}\right)$ and others are also formed. That is, it is expedient to implement a system of biological purification of industrial gases with the involvement of the chlorophyllsynthesizing microalgae using combustion products as components of the nutrient medium. Therefore, our task was to find the concentrations ratio of $\mathrm{SO}_{2}: \mathrm{N}_{\mathrm{x}} \mathrm{O}_{\mathrm{y}}: \mathrm{P}_{2} \mathrm{O}_{5}$ for the optimum 
development of chlorophyll-synthesizing Chlorella microalgae and maximum absorption of $\mathrm{CO}_{2}$ carbon dioxide.

In order to study the inhibition suppression effect by sulfur dioxide $\mathrm{SO}_{2}$, the simultaneous action of two activators $-\mathrm{P}_{2} \mathrm{O}_{5}$ phosphorus oxide and $\mathrm{N}_{\mathrm{x}} \mathrm{O}_{\mathrm{y}}$ nitrogen oxides, the process of carbon dioxide absorption by chlorophyllsynthesizing microalgae, Chlorella vulgaris was used. The microalgae were cultured for 12 days in six $1 \mathrm{dm}^{3}$ photobioreactors. The nutrient medium in which the microalgae developed and grew was natural, i.e. the water together with the culture of Chlorella microalgae was taken from a natural reservoir (pond). In order to create the most favorable conditions for the reproduction of microalgae, the temperature was maintained within $t=30^{\circ} \mathrm{C}$ using thermostats. Moreover, every day the samples were additionally saturated with the main nutrient $\mathrm{CO}_{2}$ carbon dioxide to create the most favorable conditions for the cultivation of microalgae. As the $\mathrm{P}_{2} \mathrm{O}_{5}, \mathrm{~N}_{\mathrm{x}} \mathrm{O}_{\mathrm{y}}$ and $\mathrm{SO}_{2}$ oxides are assimilated by microalgae in the form of $\mathrm{H}_{2} \mathrm{PO}_{4}^{-}$; $\mathrm{NO}_{3}^{-}$; $\mathrm{HSO}_{3}{ }^{-}$anions, their effect on the growth of chlorophyll-synthesizing microalgae was studied at different concentration values $\left(\mathrm{H}_{2} \mathrm{PO}_{4}^{-} ; \mathrm{NO}_{3}^{-}\right)$ at a constant concentration $\left(\mathrm{HSO}_{3}^{-}\right)$. The value of the inhibitor $\left(\mathrm{HSO}_{3}^{-}\right)$critical concentration was established experimentally and given in the work (Dyachok et al., 2017). Moreover, the working concentrations of $\mathrm{H}_{2} \mathrm{PO}_{4}^{-} ; \mathrm{NO}_{3}^{-}$anions were experimentally established and given in the articles (Dyachok et al., 2020).

In order to study the effect of the simultaneous action of phosphorus oxide $\left(\mathrm{P}_{2} \mathrm{O}_{5}\right)$ and nitrogen oxides $\left(\mathrm{N}_{\mathrm{x}} \mathrm{O}_{\mathrm{y}}\right)$ activators in the presence of a sulfur oxide inhibitor $\left(\mathrm{SO}_{2}\right)$ in the first photobioreactor, only the anion with a concentration of $1000 \mathrm{mg} /$ $\mathrm{m}^{3}$ was added to ensure that sulfur dioxide is an inhibitor of biomass growth of chlorophyllsynthesizing microalgae such as Chlorella. In the second photobioreactor, the authors added the $\mathrm{HSO}_{3}^{-}$anion with a concentration of $1000 \mathrm{mg} / \mathrm{m}^{3}$, the $\mathrm{H}_{2} \mathrm{PO}_{4}^{-}$anion with a concentration of 0.002 $\mathrm{mg} / \mathrm{m}^{3}$ and the $\mathrm{NO}_{3}^{-}$anion with a concentration of $8.6 \mathrm{mg} / \mathrm{m}^{3}$; in the third $\mathrm{HSO}_{3}^{-}-1000 \mathrm{mg} / \mathrm{m}^{3}$, $\mathrm{H}_{2} \mathrm{PO}_{4}^{-}-0.004 \mathrm{mg} / \mathrm{m}^{3}$ and $\mathrm{NO}_{3}^{-}-13.7 \mathrm{mg} / \mathrm{m}^{3}$; in the fourth $\mathrm{HSO}_{3}^{-}-1000 \mathrm{mg} / \mathrm{m}^{3}, \mathrm{H}_{2} \mathrm{PO}_{4}^{-}-0.005$ $\mathrm{mg} / \mathrm{m}^{3}$ and $\mathrm{NO}_{3}^{-}-17.2 \mathrm{mg} / \mathrm{m}^{3}$ and in the fifth $\mathrm{HSO}_{3}^{-}-1000 \mathrm{mg} / \mathrm{m}^{3}, \mathrm{H}_{2} \mathrm{PO}_{4}^{-}-0.006 \mathrm{mg} / \mathrm{m}^{3}$ and $\mathrm{NO}_{3}^{-}-21.2 \mathrm{mg} / \mathrm{m}^{3}$. That is, the same amount of $\mathrm{HSO}_{3}^{-}$anion and different number of $\mathrm{H}_{2} \mathrm{PO}_{4}^{-}$and
$\mathrm{NO}_{3}{ }^{-}$were added to all samples, same as a control solution that did not contain any other anions throughout the study.

The increase in the biomass of chlorophyllsynthesizing microalgae under such conditions was determined with the photocolorimetric method using a blue light filter according to the Beer-Lambert law (Poltorak et al., 1972). Since the optical density is proportional to the content, therefore, the experimental data on the accumulation of microalgae biomass depending on time within the studied total concentration of the $\mathrm{HSO}_{3}^{-} ; \mathrm{H}_{2} \mathrm{PO}_{4}^{-} ; \mathrm{NO}_{3}^{-}$anions correspond to the values of optical densities.

\section{RESULTS AND DISCUSSION}

When processing the experimental data, a graphical dependence was obtained, which illustrates the change in the increase of the microalgae content in the culture medium over time at different values of anion concentrations $\left(\mathrm{H}_{2} \mathrm{PO}_{4}^{-} ; \mathrm{NO}_{3}^{-}\right)$and a constant value of inhibitor concentration $\mathrm{HSO}_{3}^{-}$with a single introduction (Fig. 1).

While analyzing the data obtained from Figure 1, the authors made sure that the $\mathrm{HSO}_{3}{ }^{-}$ anion is an inhibitor of the carbon dioxide absorption process, which is reflected in the microalgae biomass increase. Namely, in Figure 1 , it is clear that the growth and development of microalgae in the first sample is significantly slowed down compared to the control and other samples. Moreover, it should be noted that the increase in the concentration of the Chlorella microalgae cells significantly depends on the concentration of $\mathrm{H}_{2} \mathrm{PO}_{4}^{-}$and $\mathrm{NO}_{3}^{-}$anions, which act as activators of the $\mathrm{CO}_{2}$ carbon dioxide uptake process. From the second to the fourth sample, it was observed that the anions $\left(\mathrm{H}_{2} \mathrm{PO}_{4}^{-} ; \mathrm{NO}_{3}^{-}\right)$ inactivate the action of the inhibitor $\mathrm{HSO}_{3}^{-}$, which is accompanied by an increase in microalgae, which is even faster than in the control sample to which no other anions were added, but only a culture of microalgae and a natural nutrient medium. Attention should also be paid to the sample No. 5, which in comparison with other samples decreases rapidly, indicating that a detrimental concentration of anions $\left(\mathrm{H}_{2} \mathrm{PO}_{4}^{-}\right.$; $\mathrm{NO}_{3}^{-}$) was added at the declared concentration $\mathrm{HSO}_{3}^{-}$, for the growth and development of microalgae Chlorella. 


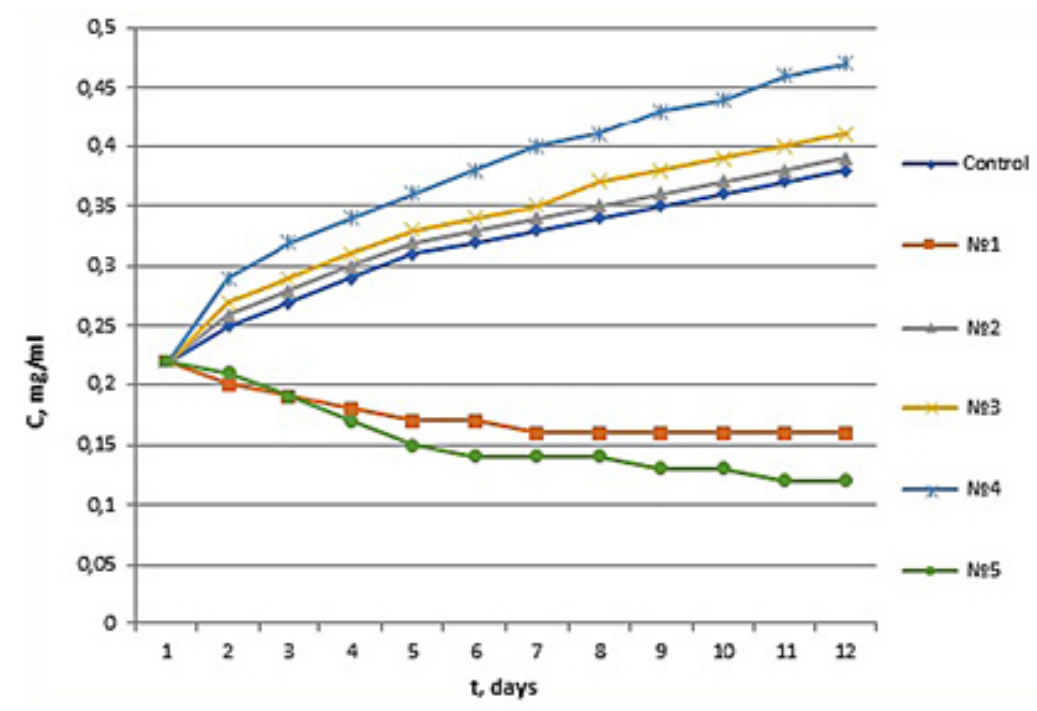

Fig. 1. The dependence of the change in the content of microalgae cells in the suspension over time at appropriate concentrations of $\mathrm{HSO}_{3}^{-} ; \mathrm{H}_{2} \mathrm{PO}_{4}^{-} ; \mathrm{NO}_{3}^{-}$

The determining parameter that characterizes the growth of microalgae $\delta_{\mu}$ is the specific growth rate:

$$
\delta_{k}=\delta C_{1} / C \times \delta t
$$

where: $C$ - the content of microalgae in the culture medium (suspension),

$\delta_{\mu}$-specific growth rate or specific growth coefficient $\left(\mathrm{c}^{-1}\right)$.

In addition, the growth coefficient can be determined from the equation:

$$
\delta C / \delta t=\mu \times C
$$

According to the equation, the growth coefficient characterizes the relative increase in the density of microalgae per unit time. If for a certain time $\delta \mu$ remains unchanged, then such an increase is called exponential, and the corresponding period of time - the exponential growth phase. Having integrated equation (2), the integration constant is found provided that at the initial time $t=0$ there is an initial content of cells of microalgae $C_{0}$ in suspension:

$$
C=C_{0} \times \exp (\mu t)
$$

Since the logarithmic dependence of the microalgae cells content on time during the period of exponential growth is a linear dependence, it enables to determine the growth coefficient $\mu$ as the tangent of the inclination angle of the experimental line (Manakov et al., 1990). Therefore, substituting the experimental data in equation (3), we obtain the dependences Ln $C=f(t)$, which are depicted in (Fig. 2; 3).

Using the lines obtained from the figures (Fig. 2; Fig. 3), the growth coefficient $\mu$ was

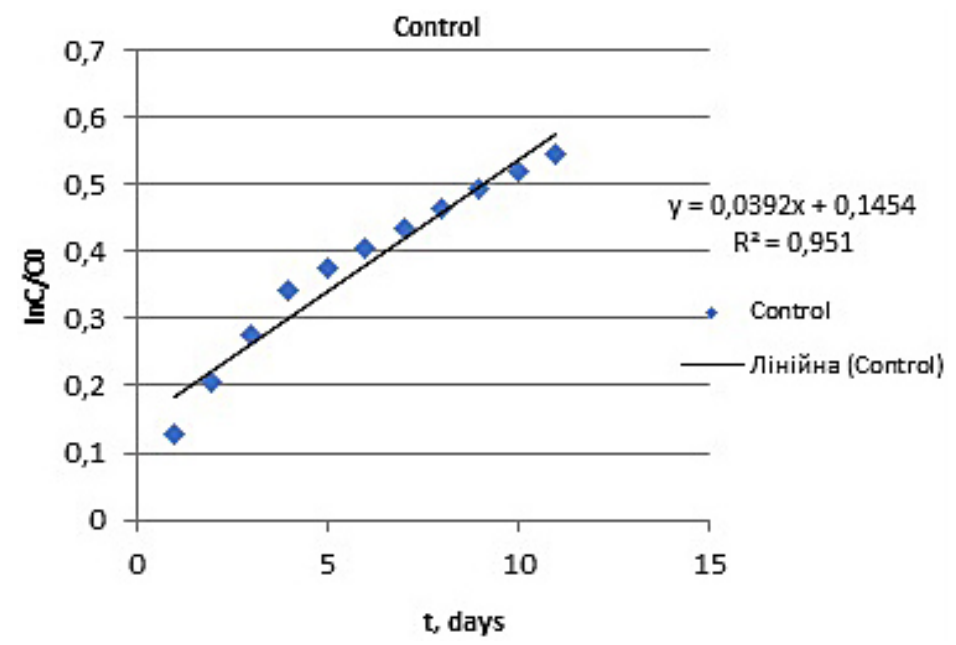

Fig. 2. Dependence of logarithm change of the microalgae cells content in suspension on time (control) 


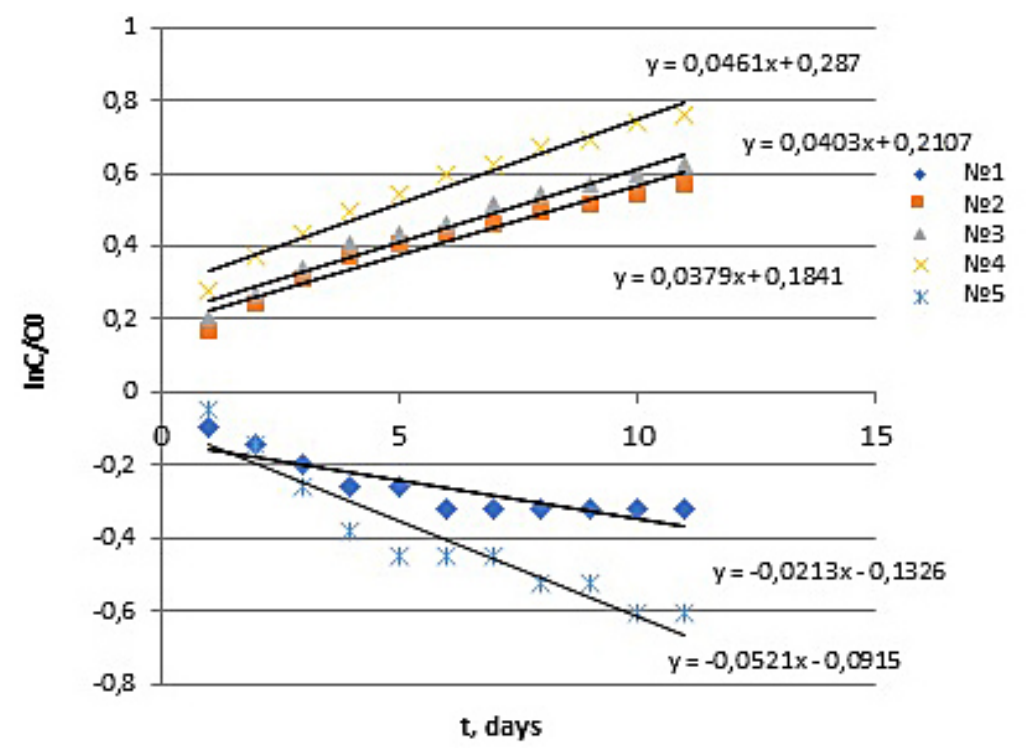

Fig. 3. Dependence of the change in the logarithm of the microalgae cells content in the suspension on time (at the corresponding concentrations of activators $\left(\mathrm{H}_{2} \mathrm{PO}_{4}^{-} ; \mathrm{NO}_{3}^{-}\right)$and the inhibitor $\mathrm{HSO}_{3}^{-}$

Table 1. Experimental data and calculated values

\begin{tabular}{|c|c|c|c|c|}
\hline Sample & $\begin{array}{c}\mu \text { growth coefficient, } \\
\mathrm{c}^{-1}\end{array}$ & $\begin{array}{c}\mathrm{HSO}_{3}^{-} \text {concentration, } \\
\mathrm{mg} / \mathrm{m}^{3}\end{array}$ & $\begin{array}{c}\mathrm{H}_{2} \mathrm{PO}_{4}^{-} \text {concentration, } \\
\mathrm{mg} / \mathrm{m}^{3}\end{array}$ & $\begin{array}{c}\mathrm{NO}_{3}^{-} \text {concentration, } \\
\mathrm{mg} / \mathrm{m}^{3}\end{array}$ \\
\hline Control & 0.0392 & - & - & - \\
\hline Sample No. 1 & -0.0213 & 1000 & - & 8.6 \\
\hline Sample No. 2 & 0.0379 & 1000 & 0.002 & 13.7 \\
\hline Sample No. 3 & 0.0403 & 1000 & 0.004 & 17.2 \\
\hline Sample No. 4 & 0.0461 & 1000 & 0.005 & 21.2 \\
\hline Sample No. 5 & -0.0521 & 1000 & 0.006 & - \\
\hline
\end{tabular}

determined. The obtained dependences allowed determining the growth factor $\mu$ as the tangent of the inclination angle of the experimental lines. Since there is an increase in the growth of microalgae biomass in the control tank, the value of the growth coefficient is positive, $\mu=$ $0,0392 \mathrm{c}^{-1}$ (Fig. 2). The values of the growth coefficients $\mu$ at constant concentrations of inhibitor $\mathrm{HSO}_{3}^{-}$and the corresponding concentrations of activators $\left(\mathrm{H}_{2} \mathrm{PO}_{4}^{-} ; \mathrm{NO}_{3}^{-}\right)$ are shown in Table 1. In samples 2-4, there is an increase in Chlorella microalgae biomass; therefore, the value of the growth coefficients is positive. Since only the inhibitor was added to the sample No. 1 - there is a decrease in the growth of microalgae biomass, so the value of the growth factor $\mu$ is negative. In the case of sample No. 5 the value of the growth factor $\mu$ is negative and there is a decrease in the growth of microalgae biomass, which indicates a detrimental concentration of anions $\left(\mathrm{H}_{2} \mathrm{PO}_{4}^{-} ; \mathrm{NO}_{3}^{-}\right)$at the declared concentration $\mathrm{HSO}_{3}^{-}$in this sample.
On the basis of the data of experimental studies and mathematical processing of the results, it is seen that the maximum increase of chlorophyll-synthesizing Chlorella microalgae is achieved by the ratio of the $\mathrm{H}_{2} \mathrm{PO}_{4}^{-} ; \mathrm{NO}_{3}^{-}$; $\mathrm{HSO}_{3}^{-}$anions concentrations; which were added to the fourth sample. Namely, in Figure 1 it is clear that the sample No. 4 has the most rapid increase compared to other samples. Moreover, after mathematical processing of the results and obtained during the study of growth coefficients $\mu$, it can be seen from Table 1 that the highest growth rate is in the sample No. 4 $\mu=0.0461 \mathrm{c}^{-1}$.

Therefore, the most favorable for the growth and development of Chlorella microalgae, and therefore the most efficient absorption of carbon dioxide by microalgae are at the following anion concentrations: $\mathrm{HSO}_{3}^{-}=1000 \mathrm{mg} / \mathrm{m}^{3} ; \mathrm{H}_{2} \mathrm{PO}_{4}^{-}=$ $0,005 \mathrm{mg} / \mathrm{m}^{3} ; \mathrm{NO}_{3}^{-}=17,2 \mathrm{mg} / \mathrm{m}^{3}$ provided that the content of microalgae in the suspension is not less than $0.22 \mathrm{mg} / \mathrm{ml}$. 
On the basis of the data obtained during the experimental study and mathematical processing of the results, the optimum ratio of the anions concentration can be determined. Under such conditions, carbon dioxide is absorbed the most, which is confirmed by the dynamics of biomass growth.

The mathematical model that describes the growth dynamics of microalgae and, accordingly, the dynamics of carbon dioxide absorption of $\mathrm{CO}_{2}$ has the form:

$$
\left\{\begin{array}{l}
\frac{d C}{d x}=\mu_{1} C-\mu_{2} C \\
\frac{d C}{d x}=\mu_{1} C \\
x=0, C=C_{o}
\end{array}\right.
$$

where: $x$ - activators concentrations $\mathrm{H}_{2} \mathrm{PO}_{4}^{-}$; $\mathrm{NO}_{3}^{-}$under conditions of constant inhibitor concentration $\mathrm{HSO}_{3}^{-}$;

$C$ - microalgae content in the suspension.

The solution of this model has several analytical expressions, one of them allows calculating the optimum concentration of the activator in the presence of the inhibitor under the condition of its constant concentration and known values of growth coefficients $-\mu$;

$$
x_{\max }=\frac{\ln \mu_{2}-\ln \mu_{1}}{\left(\mu_{1}+\mu_{2}\right)}
$$

This means that the mathematical model (4) and its solution (5) quite correctly describe the course of the studied phenomenon, and its solution allows predicting the main parameters of greenhouse gas absorption technology in the presence of inhibitor - $\mathrm{SO}_{2}$ sulfur dioxide, $\mathrm{P}_{2} \mathrm{O}_{5}$ phosphorus and $\mathrm{N}_{\mathrm{x}} \mathrm{O}_{\mathrm{y}}$ nitrogen oxides activators.

\section{CONCLUSIONS}

The article investigated the phenomenon of $\mathrm{SO}_{2}$ sulfur oxide inhibitor inactivation under the condition of its constant concentration by the simultaneous action of two activators $-\mathrm{P}_{2} \mathrm{O}_{5}$ phosphorus oxide and $\mathrm{N}_{\mathrm{x}} \mathrm{O}_{\mathrm{y}}$ nitrogen oxides for the carbon dioxide absorption process by chlorophyll-synthesizing Chlorella microalgae. The experimental results of studies on the efficiency of carbon dioxide absorption by Chlorella microalgae depending on a ratio of activators concentration at constant concentration of inhibitor were presented.
During the experimental study and subsequent mathematical processing of the results, the optimum ratio of the concentration of anions $\mathrm{HSO}_{3}{ }^{-}$ $=4545,45: \mathrm{H}_{2} \mathrm{PO}_{4}^{-}=0,022: \mathrm{NO}_{3}^{-}=78,18 \mathrm{mg} /$ $\mathrm{ml}$ by microalgae content in suspension of at least $0.22 \mathrm{mg} / \mathrm{ml}$, which leads to the most intensive absorption of carbon dioxide, was determined. The obtained results allow predicting the parameters of the technological process of industrial gas emissions purification from major greenhouse gases such as carbon dioxide $\left(\mathrm{CO}_{2}\right)$, sulfur oxide $\left(\mathrm{SO}_{2}\right)$, phosphorus oxide $\left(\mathrm{P}_{2} \mathrm{O}_{5}\right)$ and nitrogen oxides $\left(\mathrm{N}_{\mathrm{x}} \mathrm{O}_{\mathrm{y}}\right)$ with the participation of chlorophyll-synthesizing Chlorella microalgae.

\section{REFERENCES}

1. Dyachok V., Huhlych S., Katysheva V.V., Mandryk S.T. 2017. Absorption of carbon dioxide from a mixture of air with sulfur dioxide (in Ukrainian). Naukovi Pratsi Onakht, 81(1), 59-65.

2. Dyachok V.V., Mandryk S.T., Huhlych S.I., Slyvka M.M. 2020. Study on the impact of activators in the presence of an inhibitor on the dynamics of carbon dioxide absorption by chlorophyll-synthesizing microalgae. Journal of Ecological Engineering, 21(5), 189-196.

3. Chlorella in sewage treatment (in Ukrainian), 2020. Retrieved from: https://hlorella.jimdo.com/.

4. Manakov M.N., Pobedimskiy D.H. 1990. Theoretical bases technology of microbiological productions technology (in Ukrainian). Ahropromisdat, pp. 272.

5. $67 \%$ of greenhouse gas emissions are caused by energy and burning of fossil fuels (in Ukrainian), 2020. Ofitsiyhyy portal Ministerstva zakhystu dovkilla i pryrodnykh resursiv Ukrainy. Retrieved from: https://mepr.gov.ua/news/34553.htm.

6. Poltorak O.M., Chukhray O.S. 1972. Physicochemical bases of enzymatic catalysis (in Ukrainian). In: M.M. Poplavskaya (Ed.). Vysshaya shkola, pp. 311.

7. Project of Ukrainian Green transition Concept by 2050 (in Ukrainian). Ministerstvo enerhetyky ta zakhystu dovkilla Ukraine. Retrieved from: https:// www.kmu.gov.ua/news/prezentovano-proekt-koncepciyi-zelenogo-energetichnogo-perehodu-ukrayini-do-2050-roku.

8. Climate change (in Ukrainian), 2020. Natsionalnyy ekolohichnyy tsentr Ukrainy. Retrieved from: necu. org.ua/climate/.

9. Zolotaryova O.K., Shnyukova Ye.I., Syvash O.O., Mykhaylenko N.F. 2008. Prospects for the use of microalgae in biotechnology (in Ukrainian). In: O.K. Zolotaryovoa (Ed.) Alterpres, pp. 234. 